\title{
THE BEHAVIORAL ECOLOGY OF MATERNAL EFFORT IN FUR SEALS AND SEA LIONS
}

\author{
by
}

FRITZ TRILLMICH $\left.{ }^{i}\right)^{2}$ )

(Max-Planck Institut für Verhaltensphysiologie, Abt. Wickler, D-8131 Seewiesen, FRG)

\section{Introduction}

Mammals are surprisingly flexible in their rearing strategies (BOYce, 1988). Few investigations have addressed the question which mechanisms produce this flexibility and it is even less clear which of the observed responses are adaptive answers to environmental challenges and which just unavoidable consequences of the animal's physiological and behavioral constraints. While we are still far from complete answers to these difficult questions progress has been made by comparative studies. One drawback of comparative studies is that the genetic differences between species are usually unknown and confound interpretations of adaptive trends. It would therefore be advantageous to study intraspecific changes in rearing strategies in response to changes in environmental parameters.

Fur seals and sea lions, the eared (otariid) seals, are an eminently suitable group for the comparative study of maternal strategies: species are behaviorally, physiologically and morphologically similar and yet they live in widely different habitats from subpolar seas to tropical

1) I would like to thank the many colleagues who work on maternal strategies in seals and have clarified my thinking through many most fruitful discussion. Dieter Schmide prepared the Figures. I am particularly indebted to G. L. Kooyman for sharing ideas and introducing me to experimental approaches to pinniped behavior. W. WICKLER supported my work in Galapagos. W. Arnold, P. Hammerstein, W. Wickler and P. WIRTZ criticized and suggested changes to the manuscript. The work on Galapagos fur seals was supported by the Max-Planck Gesellschaft through the Institute in Seewiesen and the work on Galapagos fur seal energetics was additionally supported by the Deutsche Forschungsgemeinschaft through grant $\operatorname{Tr} 105 / 4$.

$\left.{ }^{2}\right)$ Present address: Lehrstuhl für Verhaltensforschung, Universität Bielefeld, Postfach 8640 , D-4800 Bielefeld, B.R.D. 
upwelling ecosystems (Gentry \& Kooyman eds, 1986). In addition, the recent major El Niño event, which caused a dramatic warming of the eastern Pacific and also influenced the Atlantic (ARNTz et al., 1985; AGU, 1987; Cane, 1986; GlynN, 1988), created an opportunity to study several species under unusual environmental conditons (Costa et al., 1989; OnO et al., 1987; Trillmich \& Limberger, 1985; Trillmich et al., ms.). Many of these species had been studied before the El Niño and thus permitted to compare the behavior of mothers under conditions of low and high or normal food availability. Many of these comparisons can only be made in a qualitative way because the changes in food resources, while qualitatively obvious, were not measured accurately.

The possibility to draw inter- and intraspecific comparisons is used here to address the question of adaptiveness or constraint in maternal strategies of female eared seals. In particular, I will review how changes in food supply influence maternal body condition and foraging, and how this in turn changes the rate of energy transfer to the pup, and pup growth rate. The relation between pup growth rate and time to weaning is discussed for species living in different environments and under different conditions in one environment, and it is briefly shown how delayed weaning influences the mother's future fertility in the Galapagos fur seal via sibling competition.

\section{Species considered and the natural history of pup rearing in eared seals}

The main emphasis will be on fur seals (genera Arctocephalus and Callorhinus), but data on the California sea lion (Zalophus californianus) are also used. Females of all 9 fur seal species look almost alike and possess similar physiological capacities (GeNTRY et al., 1986a). Female body mass ranges between $30-90 \mathrm{~kg}$, with the majority of species (8) in the $30-50 \mathrm{~kg}$ range. Fur seals occur from the north in the Bering Sea $\left(57^{\circ} \mathrm{N}\right)$ (Northern fur seal, Callorhinus ursinus), to the tropical Galapagos Islands $\left(0^{\circ} \mathrm{N} / \mathrm{S}\right)$ (Galapagos fur seal, Arctocephalus galapagoensis), to Peru $\left(15^{\circ} \mathrm{S}\right)$ (South American fur seal, Arctocephalus australis), and down to the subarctic Islands ( $\left.c a 54^{\circ} \mathrm{S}\right)$ (Antarctic fur seal, Arctocephalus gazella). Fur seals therefore permit to study how animals with a similar suite of characters pattern their reproductive effort in widely differing environments.

Three facts facilitate the analysis of the behavioral ecology of maternal effort in otariid seals: (i) Litter size is always one (with rare exceptions; Spotte, 1982), and (ii) mothers do all the pup rearing on their own with- 


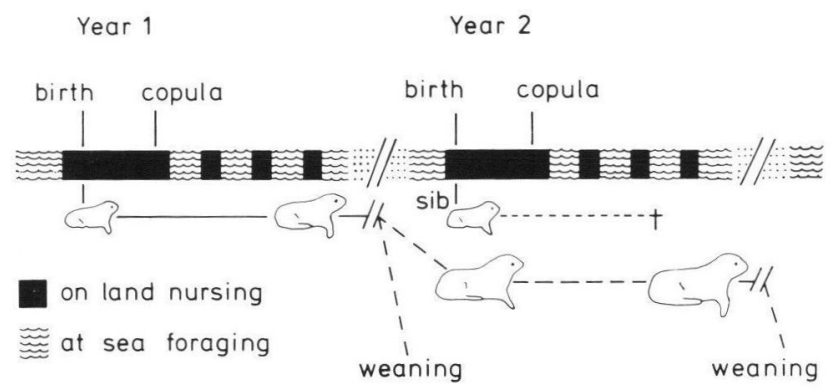

Fig. 1. The otariid rearing pattern (see text for explanation; changed after Bonner, 1984).

out any help by the male. (iii) Suckling of young is the only major maternal care activity of females.

The otariid rearing pattern basically consists of an alternation between foraging at sea and nursing on land (Fig. 1). Females come ashore a day or two before the birth of the pup. They stay with the newborn for about one week, the perinatal period. During this time the mother guards and suckles her young and individual recognition between mother and pup becomes established (Trillmich, 1981). A week post-partum, fur seal mothers enter a brief estrus, copulate, and leave a first time to forage at sea. The mother then alternates between foraging trips to sea of 1-8 days duration and 1-3 day stays ashore with the pup (Fig. 1).

Copulation leads to a fertilized zygote which is arrested in its development for about 3-4 months after which implantation takes place and embryonic development sets in. One year after giving birth females come back ashore to pup again. If rearing takes longer than a year a second pup may be born while the first one is still dependent and competition for mother's milk sets in between the older and the younger pup (Fig. 1; Trillmich, 1986a).

To understand pinniped pup provisioning strategies the foraging behavior of pinnipeds was investigated over the last few years. Instruments have been developed and deployed on several species of pinnipeds which record the time, duration and depth of every dive (Kooyman et al., 1983; Kooyman, 1989).

Fur seals dive mostly during the hours of local darkness and to relatively shallow depths. This was documented best for the Antarctic fur seal (Croxall et al., 1985) which feeds almost exclusively on krill 


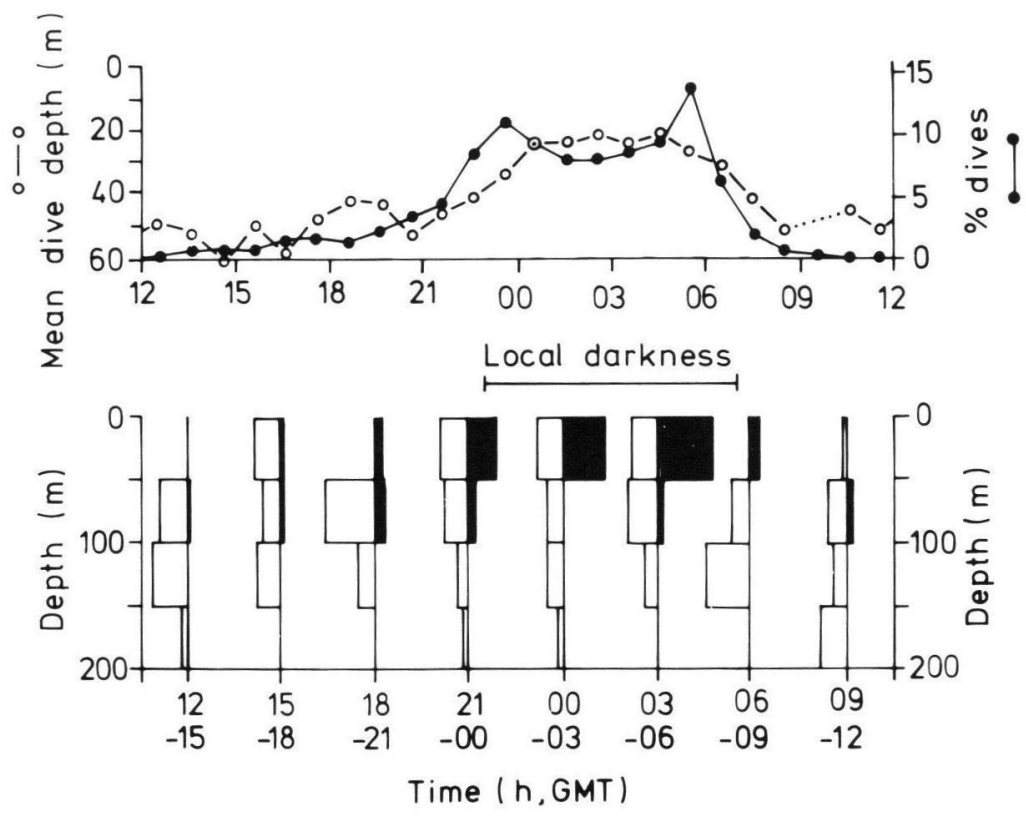

Fig. 2. Dive pattern of the Antarctic fur seal in relation to vertical migration of krill, its main prey (after Croxall et al., 1985). Upper panel: diurnal changes in dive depth (open dots) and dive activity (black dots). Lower panel: depth distribution of krill (white bars, to left) from fisheries survey adds up to $100 \%$ in each subgraph. Percent of fur seal dives (as \% of total diving activity over $24 \mathrm{hrs}$; black bars, to the right) ending at each depth interval. Diving activity of $<1 \%$ is overemphasized for visibility on the graph.

(Euphausia superba), a small, very abundant euphausiid shrimp (DoIDge \& Croxall, 1985). Krill migrate towards the surface during the night and return to depth in the morning (Fig. 2). Antarctic fur seals dive towards krill as it comes up in the evening, keep diving shallowly while it is at the surface and follow its morning descent for a while before they give up (Fig. 2; Croxall et al., 1985).

Similar to the Antarctic fur seal, other fur seal species are mostly night divers that forage on organisms of the deep scattering layer. They feed on small fishes and cephalopods, when vertical migration brings them near the surface at night. Only the Northern fur seal seems to have the option of feeding during day and night (GENTRY et al., 1986b), a behavior which is shown by sea lions as well (KoOYMAN \& Trillmich, 1986; FeldKamp et al., 1989). 


\section{Environmental influences on pup rearing strategies}

The duration of pup rearing.

The subpolar fur seals, the Northern and the Antarctic fur seal, live under conditions of pronounced seasonality. They rear their young during the highly predictable peak of food availability. In contrast, the tropical Galapagos fur seal lives in an upwelling environment with only weak seasonality in which food abundance is rather unpredictable. Fur seals in subtropical or temperate zones (all in the genus Arctocephalus), as well as the California sea lion, live under intermediate conditions, but the behavioral ecology of the temperate fur seal species is less known.

Latitude and weaning age of young are negatively correlated (Trillmich \& Lechner, 1986). The two subpolar species wean their young at an age of about 4 months. The temperate species need about 10-12 months and the only low latitude species, the Galapagos for seal takes 1-3 years until its young are weaned (Gentry et al., 1986a). Obviously, latitude is only a rough index of environmental conditions: the expected relationship between latitude and time to weaning is weak or absent among temperate species (OfTEDAL et al., 1987). This observation stresses the need for a better characterization of the environmental (and genetic) factors responsible for interspecific differences in weaning age.

Nevertheless, one important difference between the subpolar and the temperate and tropical rearing strategy is clearly related to the environment: the two subpolar species wean their pups at an age of 4 months. At about this time winter sets in and their prey migrate to depth or away from the breeding colonies. Mother and young have to migrate as well to avoid starving. Because these animals are solitary hunters this leads to mother-pup separation.

Selection has fixed weaning time in these species. Where subpolar species have immigrated recently into more temperate areas weaning still occurs after 4 months (Northern fur seals breeding off California on San Miguel Island: DeLong et al., ms; Antarctic fur seals breeding on Marion Island: KerLey, 1985) even though other eared seals breeding at the same sites delay weaning. Here the environment markedly influences the patterning of reproductive effort: strong seasonality coupled with drastic changes in food availability selects for early weaning. 
How do mothers regulate their own body stores while provisioning their pup?

The mass which females lose during the perinatal period, when they fast for about one week while permanently staying with the newborn pup (Costa \& Trillmich, 1988), is quickly regained during the first few foraging trips. However, females do not recuperate all the mass they had immediately after parturition. Rather they appear to regulate body mass to about $90 \%$ of parturition mass in the case of the Galapagos fur seal (Trillmich, 1986a), and to roughly $80 \%$ of parturition mass in the case of the Antarctic fur seal (Costa et al., 1989). Costa \& Gentry (1986) developed the idea that mothers stabilize body mass between an upper and a lower threshold. As females come ashore, body reserves get drained through suckling and the metabolic costs of fasting on land until body reserves reach a lower threshold which induces the female to leave her pup to forage at sea. She then forages until her reserves are replenished to an upper threshold at which point she returns to her pup.

TABLE 1. Mass at parturition $\left(\mathrm{M}_{\mathrm{P}}\right)$ and after the second foraging trip to sea $\left(\mathrm{M}_{2}\right)$ of Antarctic fur seal females in 1984 and 1985

\begin{tabular}{ccc}
\hline & & \\
& $\mathrm{M}_{\mathrm{P}}$ & \multicolumn{1}{c}{$\mathrm{M}_{2}$} \\
\hline & & \\
1984 & $35.6 \pm 1.8$ & $27.3 \pm 1.2$ \\
1985 & $40.2 \pm 1.0$ & $34.0 \pm 1.6$ \\
\hline
\end{tabular}

(from Costa et al., 1989).

However, Antarctic fur seal females stabilized body mass at quite different levels in the two years of the study by Costa et al. (1989) (Table 1). These data do not support a simple threshold model. Antarctic fur seals in the poor year 1984 stabilized their body mass at only about 28 $\mathrm{kg}$ while in 1985, the much better year, body mass was about $25 \%$ higher. Similarly Galapagos fur seal females weighed about $27 \mathrm{~kg}$ in years when food was less abundant and about $30 \mathrm{~kg}$ in better years (Trillmich, unpubl. data). It is not clear whether females which do not incur the cost of rearing young show the same mass changes from poor to good years, but very likely mass reduction is the inevitable outcome 
of a lowered foraging efficiency. For example, in Antarctic fur seals mean maternal mass at parturition was $37.2 \mathrm{~kg}$ in the food-poor year 1983-84 (Costa et al., 1988) whereas in the food-richer year, 1987, parturition mass was $47.3 \mathrm{~kg}$ (Boyd \& MCGANN, 1989). Since females are expected to store a maximal amount of nutrients for the perinatal fasting period before coming ashore to pup, these data indicate that low food availability acts as an environmental constraint reducing the foraging success and therefore the body mass of female fur seals.

Foraging behavior of mothers and its changes with changing food resources.

Which changes in foraging behavior could explain changes in body mass and how do mothers achieve to keep body mass relatively stable while provisioning a pup under conditions of variable food resources? Digging into body stores is obviously only a short-term solution to the problem of maintaining a constant level of pup provisioning. So, during years of low food abundance, females could either stay longer at sea hunting with the same effort, or they could increase foraging effort and stay at sea for the same period. Of course, females may also combine these two options.

When food becomes scarce, as during El Niño, lactating females of most species tend to stay at sea longer before they return to their pups (Fig. 3). This increase in trip duration is very marked in Antarctic and Galapagos fur seals, much less so in California sea lions, and is not significant for Northern fur seals.

Comparing the metabolic rates of these species under conditions of different food abundance (Fig. 4) we find that the two species which showed little or no significant increase in trip duration, considerably increased energy utilization while at sea, whereas the Antarctic fur seal and Galapagos fur seal, which responded most clearly by increasing time at sea, worked at nearly the same effort.

How can these interspecific differences in reaction to poor food conditions be explained? The most likely explanation is in terms of shifts in the time budget (Costa et al., 1989). Besides diving, Northern fur seals rest for $17 \%$ and swim for $60 \%$ of their time at sea. Similarly, California sea lions rest $4 \%$ and swim $48 \%$ of their time at sea. These animals can increase their foraging effort while at sea by reducing the time spent resting or swimming and increasing the time spent diving. Swimming is less expensive per unit time than diving because diving is done at higher mean speeds (Ponganis et al., submitted). If so, the higher mean rate of 


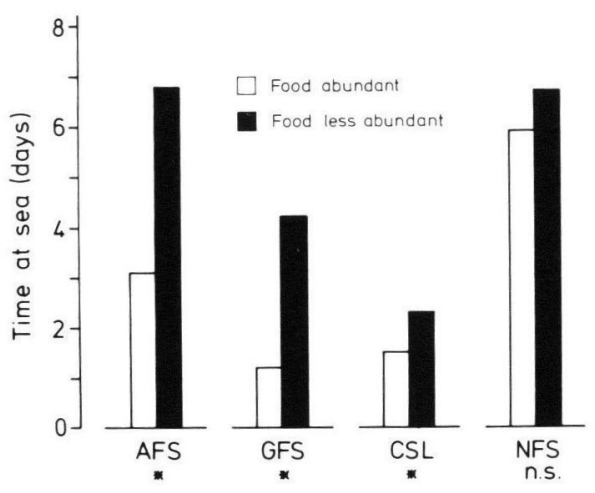

Fig. 3. Time mothers spent away from their pups under conditions of normal and low food abundances. AFS = Antarctic fur seal, GFS = Galapagos fur seal, CSL = California sea lion, NFS = Northern fur seal (sources: Croxall et al., 1988; Trillmich \& DellINGER, ms; ONO et al., 1987; GENTRY, ms). ${ }^{*}=\mathrm{P}<0.05 ;$ n.s. $=$ non significant.

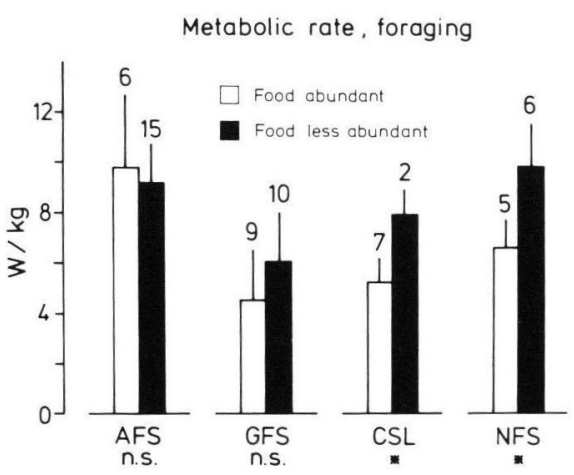

Fig. 4. Energy expenditure of mothers while away from their pups foraging at sea. Numbers above columns are sample sizes (sources: Costa et al., 1989; Trillmich \& Kooyman, unpubl. data; Costa et al., ms; Costa \& Gentry, 1986). Numbers above bars give sample size. Abbreviations and symbols as Fig. 3.

energy expenditure of foraging Northern fur seal and Cialifornia sea lion females reflects their increase in diving effort. California sea lions as well as Northern fur seals can increase total dive time by continuing to dive during the daytime. In fact California sea lion's were found to increase the duration of dive bouts and the total time spent diving, reduce the time spent swimming and to make more long, deep dives under poor food conditions (FeldKamp et al., ms). 
Apparently this change in behavior is not possible for Antarctic and Galapagos fur seals because they cannot economically reach their prey during the day when it stays deep down: their foraging time window is narrower. In addition Antarctic fur seal females are food specialists which do not switch to different prey items when krill becomes scarce.

In summary, females of two species react to reduced food abundance by increasing the rate of energy expenditure and partly switching to different prey sources, whereas females of the other two species stick to the same or a very similar resource and have to stay at sea for a longer period until body reserves are restored to an acceptable level. Changes in foraging behavior more likely reflect adaptive responses to changes in distribution, daily vertical migration and abundance of food organisms rather than constraints of e.g. physiological diving capacity (GENTRY et al., 1986a). But lack of knowledge about the food resources of pinnipeds remains one of the biggest problems in the study of these species.

The influence of increased time at sea on pup growth rates.

At low food availability, during the warm season, Galapagos fur seal mothers stay at sea for an average 4.5 days instead of 1.2 days as in the cold season. Under these conditions pups have to fast much longer before they obtain milk again. Simultaneously, pup growth rate declines (Fig. $5)$. The reduction in growth rate is a significant effect in the Antarctic fur seal and California sea lion, but just fails to be significant in the Galapagos fur seal where growth rates of pups were measured over the first month of life only. Apparently female Galapagos fur seals were able to meet the energy demands of small pups in poor as well as in good years. During El Niño 1982-83, however, food conditions deteriorated so much that all pups died soon after birth (TRILlmich \& LiMBERGER, 1985). Even in "normal" years growth rate declines from about $50 \mathrm{~g} /$ day during the cold season, when foraging trips are short, to only $13 \mathrm{~g} /$ day during the warm season, when foraging trips are much longer, confirming the expectation. Similarly, for the South American fur seal, growth rate correlated negatively with sea surface temperature (SST) (MAJLuF, $1987 ; \mathrm{ms}$ ). SST was used as an indicator of food availability for fur seals since prey organisms do not come close to the sea surface when temperatures are high. High temperatures thus mean lowered prey density or reduced foraging efficiency.

The reduction in growth rate of pups follows because mothers produce less milk energy per unit time when foraging is less efficient. Never- 
theless, up to the threshold of starvation, an increase of maternal time at sea is beneficial to mother and pup since with little food this is the only way in which a positive energy balance of the mother-pup system can be maintained.

Below a critical threshold of food abundance, females tend to stay at sea for such a long time that the pups' probability of starvation increases rapidly. This mechanism in effect leads to pup abandonment even though mothers may still return to the pupping site as observed for fur seals and sea lions during El Niño. During the El Niño food shortage in 1982-83 pups were indeed found to die after repeated fasts of 8-10 days (Trillmich et al., ms).

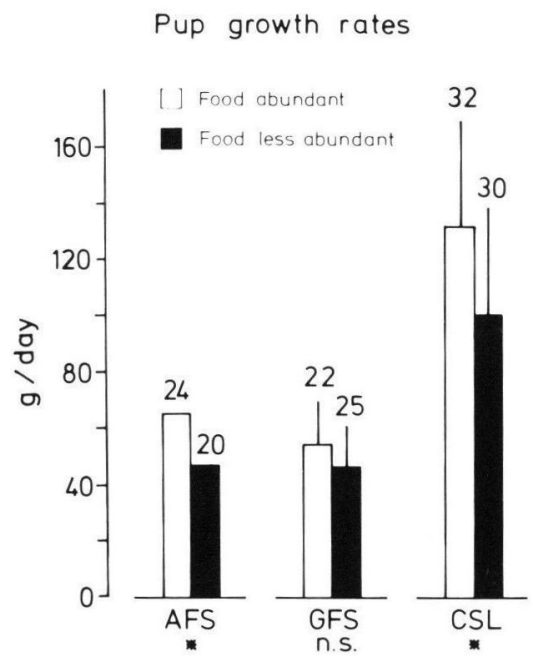

Fig. 5. Pup growth rates under good and poor food conditions (sources: Croxall et al., 1988; Trillmich, unpubl. data; ONo et al., 1987). Abbreviations and symbols as Fig. 3.

The consequence of a reduced growth rate in temperate and tropical species is an increase in the time to weaning. This in turn increases the cost of pup rearing for mothers since it extends the time of lactation (see below). Extending the lactation period is no option for subpolar fur seals since they have to wean at the end of the 4 month period when mothers and pups migrate away from the breeding colonies. In subpolar species, the mortality of pups weaned at lower mass is expected to be greater than that of fat weaners, but no data are presently available. 
The options of the pup.

Do pups have some means by which they can induce their mothers to work harder? In the Galapagos fur seal, time spent on the teat increases as pup age increases (Trillmich, 1986a). Male yearlings spent up to $80 \%$ of the first day of a mothers stay ashore on the teat. This increase in sucking time correlates with a decrease in the mother's time ashore. Mothers of yearlings were 12 hours ashore before leaving, while mothers of 1-months old pups spent 22 hours ashore before they left again (Trillmich, 1986a). Non-lactating females stay longer ashore, often for two or three days. This suggests that it is mainly milk extraction which causes mothers to return to sea for renewed foraging rather than the cost of maintenance metabolism while on shore.

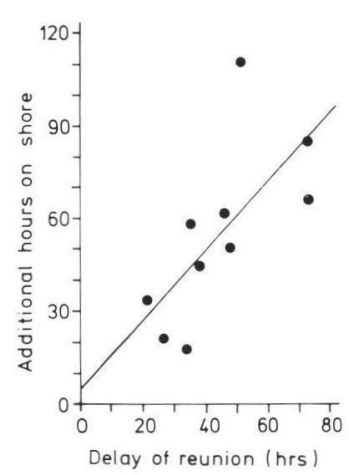

Fig. 6. The lengthening of time ashore (above the expected 2.2 day period ashore) when pups are withheld from reunion with their mothers in the Northern fur seal (after Gentry \& HolT, 1986).

That pup demand influences the length of stays ashore was shown experimentally in Northern fur seals (Gentry \& Holt, 1986). Gentry \& Hout (l.c.) captured pups at about the time when their mothers were expected to return from a foraging trip. The longer they held these pups separated from the mothers the longer the mothers stayed ashore beyond their expected staying time of 2.2 days (Fig. 6). They could also achieve this by feeding the pups before they reunited with their mothers and again mothers stayed ashore much longer. Increased extraction efficiency and long sucking times of older pups thus lead to an earlier departure of the mother and more time foraging. But since time at sea is usually much 
longer than time ashore this mechanism will only rarely increase energy flow to the pup by more than $10 \%$.

Since sucking time correlates with milk uptake (Trillmich, 1986b) older pups should get more milk when they suck so much longer. It seems, however, very unlikely that milk yield increases linearly with sucking time over long periods. Presumably, the rate of milk yield declines with the time the mother is present so that much of the late sucking activity is non-nutritive. However, if pups can inform their mothers about their food requirements by the duration and intensity of sucking, this may compensate a little for the longer time mothers spend at sea during poor food conditions. Also, prolonged sucking may slightly increase overall milk yield as is documented for many other mammals.

Maternal mechanisms reducing the impact of lowered food abundance on pup development.

Milk analysis of samples from the Galapagos fur seal, revealed another mechanism which would aid to compensate a little for the longer trip duration of mothers under poor food conditions: milk fat content increased from about $25 \%$ during the cold season, when mothers stayed at sea for about 1.5 days, to $38 \%$ in the warm season, when mothers were absent for 4.5 days on average (Trillmich \& Lechner, unpubl. data). The increase in milk fat content with increasing absence time seems to be a general trend in otariid seals (Trillmich \& Lechner, 1986). For example, Northern fur seal females are known to increase the trip duration as pups get older (Gentry \& Holt, 1986) and Costa \& Gentry (1986) reported that fat content also increases over the rearing period.

The increase in fat content does not compensate fully for the increase in absence duration. Norhtern fur seal females would have to increase the volume of milk transferred by $7 \%$ per additional day of absence from the pup to provide an identical milk energy yield. Such an increase in milk yield is unlikely, but no direct measurments of milk yield are presently available. But Gentry \& Holr (1986) reported that Northern fur sealpups on St. Paul Island grow slower than pups of the same species on St. George Island. The only difference between the two islands is that mothers from St. Paul have to travel further to the shelf-break feeding areas and thus tend to stay away from their pups for slightly longer. Obviously they are unable to compensate this increase in absence time through a corresponding increase in milk fat content and milk yield. Another indication that milk volume does not increase with increased 
time at sea is data by ONo et al. (1987) who showed that during El Niño California sea lion pups spent less time suckling and were obviously getting less milk than in normal years. The outcome of increased time at sea is, therefore, a lowered growth rate of young.

\section{Ultimate costs of lowered provisioning rates}

Females cannot fully compensate their pups' milk intake for increased time at sea by phisiological mechanisms which shows the physiology of milk production to be a real constraint on the patterning of maternal effort. As a consequence, the mass of yearling Galapagos fur seals varies from year to year (Fig. 7) depending upon marine conditions. Growth rates of Antarctic fur seals also vary among years (Croxall et al., 1988) which will lead to corresponding changes in weaning mass and presumably to correlated fluctuations in the survival rate of weaners.

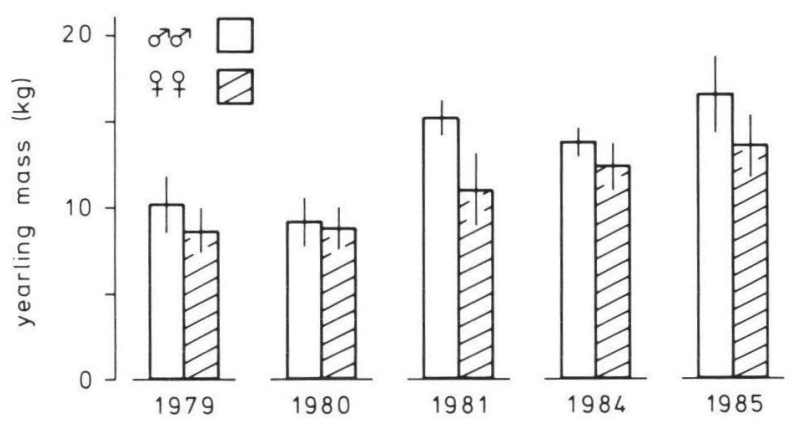

Fig. 7. Interannual variation in yearling body mass in the Galapagos fur seal (Trillmich, unpubl. data). Sample size: males, females: 1979, 14, 21; 1980, 23, 21; $1981,12,13 ; 1984,8,16 ; 1985,24,26$.

Non-migratory fur seals have yet another way of partly compensating for low resource availability during pup rearing. Mothers extend the period of pup care, i.e. they allow their young to continue suckling beyond one year of age (Gentry et al., 1986a). In the South American fur seal, pup mass in February of year one (when pups are about 3 month old) did not influence survival of pups into the next year (MAjLUF, 1987; in press). In other words, females can assure a high survival of pups which grow slowly by extending the duration of lactation. However, using this rearing strategy Galapagos fur seal females incur a substantial 
cost of reproduction. Females which lactate continuously while the next fetus develops have a lower probability (about $45 \%$ instead of $90 \%$ ) of giving birth to a pup in the subsequent breeding season (TRILlmich, 1986b; unpubl. data). Apparently females accompanied by a previous young allocate their energetic effort predominantly to lactation.

But even if a female gives birth to another young, she cannot realize the full value of this additional young since strong competition with the previous young may set in. Initially, mothers defend the newborn against its older sibling but the newborn obviously gets less milk than a newborn without an older sibling (Trillmich, unpubl. data). Growth is slowed down and often these pups lose mass rapidly and die (Trillmich, 1986a). In poor years, within one month after birth about $80 \%$ of the pups with yearling siblings are dead. In better years this mortality is lower, and in very good years it is as low as the mortality of newborns without an older sib, roughly $5 \%$ in the first month of life (Trillmich, unpubl. data). Mortality of newborns with older dependent siblings correlates with the size of the older young. The better feeding conditions have been in the previous year the larger the older sibs have become. A large young is more likely to get weaned when its sibling is born since a large yearling derives less benefit from maternal milk and can more successfully forage on its own than a smaller yearling.

In the Galapagos fur seal, about $30 \%$ of the mothers energy income is allocated to lactation (Trillmich \& Kooyman, unpubl. data). If this is sufficient the pup survives but growth varies among years. If this energy is not sufficient, as during the 1982-83 El Niño warm water event, pups die. If food is abundant mothers return often to their young which grow fast. Thus, a high energy transfer to the pup causes no additional cost to the mother. Measuring maternal effort by looking at the frequency of attendance and the duration of attendance would lead to the erroneous conclusion that mothers were expending more effort under good foraging conditions while they are not. We would fall into the same trap if we only measured the amount of energy transferred to young.

Indeed, mothers work at nearly the same metabolic rate under good and poor conditions (see Fig. 4). Increased transfer of energy to the pup seems to be a consequence of increased resource abundance. Through the phenotypic flexibility of the maternal foraging and rearing strategy this leads to a shorter time to weaning and a reduced cost of reproduction, at least in the Galapagos fur seal, but presumably in other nonmigratory fur seals as well. However, physiological and behavioral constraints limit the rate of energy expenditure in any given year. In years 
of low food availability this keeps mothers from reproducing annually through high fertility costs.

So far, the discussion referred to differences in maternal rearing efficiency among years. If similar differences in provisioning rate can also be caused by different resource availability to animals of different phenotypes-for example because older animals are more experienced in finding and exploiting food patches-we would conclude from behavioral or physiological measures alone that older animals expend more reproductive effort as expected from some theoretical arguments. Such a conclusion is not warranted unless one can demonstrate that allocation indeed shifted or that the costs to the parent(s) increased (as e.g. for red deer; Clutron-Brock et al., 1982).

\section{Summary}

Otariid seals form a group of similar species distributed from subpolar to tropical seas. Many species were recently studied under conditions of low and high food abundance during major oceanographic disturbances. Evidence for the phenotypic flexibility of and constraints on the rearing strategy of these species derives from inter- and intra-specific comparisons and experimental measurements. I review how changes in food abundance influence foraging behavior and energetics of mothers, pup growth rates, milk composition, weaning age, and the fertility cost of pup rearing. Eared seal females rear young by alternating between lactation ashore and foraging at sea. Subpolar fur seals always wean pups at four month of age, a trait which seems to be genetically fixed and adaptive in their highly seasonal environment. Temperate and tropical fur seals and sea lions can respond to changes in food abundnace by increasing or decreasing time to weaning. During pup rearing, mothers regulate body mass to different absolute values when abundance of food resources changes. This seems to be a constraint caused by reduced foraging efficiency at low food availability. Most species feed exclusively during the night, but sea lions (Zalophus californianus) and Northern fur seals (Callorhinus ursinus) also forage during the day by diving deeper. Females of some species increase the rate of at-sea energy expenditure at low food abundance while keeping the duration of foraging trips constant. Females of other species stay at sea longer working at the same rate. The latter species may be food specialist with a narrower time window for efficient foraging. Pups grow slower when mothers increase time at sea, and at very low food abundance pups may starve. Pups have little influence on the duration of maternal foraging trips, but may diminish the mothers' time ashore by increasing the rate of milk extraction and prolonged non-nutritive sucking. The impact of long maternal at-sea times is reduced by increasing milk fat content as time at sea increases. This mechanism does not fully compensate pup energy intake rate for longer trip durations. Non-migratory species can partly compensate for reduced pup growth rates by lengthening the lactation period. In the Galapagos fur seal ( $A$. galapagoensis), this entails a considerable cost to the mother by reducing her future fertility. Lactation reduces the probability of a successful simultaneous pregnancy and, if pregnancy succeeds, sibling competition for maternal milk ensues. Competition is usually won by the older sibling leading in many cases to the death of the newborn. The rate of energy transfer to pups is high in food-rich years and low in scarce ones. Because pups are more likely to be weaned as yearlings when juvenile growth rate is high than when it is low, high energy transfer to the pup in year " $a$ " reduces the cost of reproduction incurred in year " $a+1$ ". The flexibility of the rearing strategy of temperate 
and tropical species permits mothers to adjust phenotypically to variance in food availability thus partly masking the theoretically expected trade-offs in the life history of these species.

\section{References}

AGU (American Geophysical Union). (1987). El Niño. An AGU Chapman conference. - Reprinted from J. Geophys. Res. 92C, p. 14,187-14,479.

Arntz, W. E., Landa, A. \& Tarazona, J. (eds). (1985). "El Niño". Su impacto en la fauna marina. - Bol. Inst. Mar. Perú. Callao-Perú (special issue), pp. 224.

Bonner, W. N. (1984). Lactation strategies in pinnipeds: problems for a marine mammalian group. - Symp. Zool. Soc. Lond. 51, p. 253-272.

Boyce, M. S. ed. (1988). Evolution of life histories of mammals. - Yale University Press, New Haven, 1988.

Boyd, I. L. \& MCCANN, T. S. (1989). Pre-natal investment in reproduction by female Antarctic fur seals. - Behav. Ecol. Sociobiol. 24, p. 377-385.

Cane, M. A. (1986). El Niño. - Ann. Rev. Earth Planet. Sci. 14, p. 43-70.

Glutton-Brock, T. H., Guinness, F. E. \& Albon, S. D. (1982). Red deer: The behaviour and ecology of two sexes. - University of Chicago Press, Chicago.

Costa, D. P., Antonelis, G. A. \& DeLong, R. L. (ms). Effects of El Niño on the foraging energetics of the California sea lion. - In: Pinnipeds and El Niño: Responses to environmental stress (F. Trillmich \& $\mathrm{K}$. A. Ono, eds).

- -, Croxall, J. P. \& Duck, C. D. (1989). Foraging energetics of Antarctic fur seals in relation to changes in prey availability. - Ecology 70, p. 596-606.

- - \& Gentry, R. L. (1986). Free-ranging energetics of Norther fur seals. - In: Fur seals: Maternal strategies on land and at sea (R. L. Gentry \& G. L. Kooyman, eds). Princeton University Press, Princeton, p. 79-101.

- - \& Trillmich, F. (1988). Mass changes and metabolism during the perinatal fast: A comparison between Antarctic (Arctocephalus gazella) and Galapagos fur seals ( $A$. galapagoensis). - Physiol. Zool. 61, p. 169-169.

- - - - \& Croxall, J. P. (1988). Intraspecific allometry of neonatal size in the Antarctic fur seal Arctocephalus gazella. - Behav. Ecol. Sociobiol. 22, p. 361-364.

Croxall, J. P., Everson, I., Kooyman, G. L., Ricketts, C. \& Davies, R. W. (1985). Fur seal diving behavior in relation to vertical distribution of krill. - J. Anim. Ecol. 54 , p. $1-8$.

- -, McCann, T. S., Prince, P. A. \& Rothery, P. (1988). Reproductive performance of seabirds and seals at South Georgia and Signy Island, South Orkney Islands 1976-1986: implications for southern ocean monitoring studies. - In: Antarctic ocean and resources variability (Sahrhage, D. ed.). Springer Verlag, Berlin, p. 261-285.

Delong, R. L. \& Antonelis, G. A. (ms). Impact of the 1982-1983 El Niño on the Northern fur seal population at San Miguel Island, California. - In: Pinnipeds and El Niño: Responses to environmental stress (F. Trillmich \& K. A. Ono, eds).

Doidge, D. W. \& Croxall, J. P. (1985). Diet and energy budget of the Antarctic fur seal Arctocephalus gazella. - In: Antarctic nutrient cycles and food webs (W. R. Siegrried, P. R. Condy \& R. M. Laws, eds). Springer Verlag, Berlin, p. 543-550.

Feldkamp, S. D., Delong, R. L. \& Antonelis, G. A. (1989). Diving patterns of California sea lions, Zalophus californianus. - Can. J. Zool. 67, p. 872-883.

_- , _ \& _ (ms). Effects of El Niño 1983 on the foraging patterns of California sea lions (Zalophus californianus) near San Miguel Island, California. - In: Pinnipeds and El Niño: Responses to environmental stress (F. Trillmich \& K. A. Ono, eds).

Gentry, R. A. (ms). El Niño effects on adult northern fur seals at the Pribilof Islands. - In: Idem. 
-一, Costa, D. P., Croxall, J. P., David, J. H. M., Davis, R. W., Kooyman, G. L., Majluf, P., McCann, T. S. \& Trillmich, F. (1986a). Synthesis and conclusions. - In: Fur seals: Maternal strategies on land and at sea (R. L. Gentry \& G. L. Kooyman, eds). Princeton University Press, Princeton, p. 220-264.

- - Holt, J. R. (1986). Attendance behavior of northern fur seals. - In: Idem, p. 41-60.

- -, Kooyman, G. L. \& Goebel, M. E. (1986b). Feeding and diving behavior of Northern fur seals. In: Idem, p. 61-78.

GLYNN, P. W. (1988). El Niño southern oscillation 1982-83: Nearshore population, community and ecosystem responses. - Ann. Rev. Ecol. Syst. 19, p. 1-40.

Kerley, G. I. H. (1985). Pup growth in the fur seals Arctocephalus tropicalis and A. gazella on Marion Island. - J. Zool. Lond. 205, p. 315-324.

Kooyman, G. L. (1989). Diverse divers. - Springer Verlag. Berlin.

- - Billups, J. O. \& Farwell, W. D. (1983). Two recently developed recorders for monitoring diving activity of marine birds and mammals. - In: Experimental biology at sea (A. G. MacDonald \& I. G. Priede, eds). New York, Academic Press, p. 197-214.

- - \& Trillmich, F. (1986). Diving behavior of the Galapagos sea lion. -- In: Fur seals: Maternal strategies on land and at sea (R. L. Gentry \& G. L. Kooyman, eds). Princeton University Press, Princeton, p. 186-195.

Majluf, P. (1987). Reproductive ecology of female South American fur seals at Punta San Juan, Peru. - Ph.D. Thesis, Cambridge University, U.K.

- - (ms). El Niño effects on pinnipeds in Peru. - In: Pinnipeds and El Niño: Responses to environmental stress (F. TRILLMICH \& $\mathrm{K}$. A. ONo, eds).

Oftedal, O. T., Boness, D. J. \& Tedman, R. A. (1987). The behavior, physiology, and the anatomy of lactation in the pinnipedia. - Current Mammal. 1, p. 175-245.

Ono, K. A., Boness, D. J. \& Oftedal, O. T. (1987). The effect of a natural environmental disturbance on maternal investment and pup behavior in the California sea lion. - Behav. Ecol. Sociobiol. 21, p. 109-118.

Ponganis, P. J., Ponganis, E. P., Ponganis, K. V., Kooyman, G. L., Gentry, R. L. \& Trillmich, F. (1990). Swimming velocities in otariids. - Can. J. Zool, submitted.

Spotte, S. (1982). The incidence of twins in pinnipeds. - Can. J. Zool. 60, p. 2226-2233.

Trillmich, F. (1981). Mutual mother-pup recognition in Galapagos fur seals and sea lions: cues used and functional significance. - Behaviour 78, p. 21-42.

- - (1986a). Attendance behavior of Galapagos fur seals. - In: Fur seals: Maternal strategies on land and at sea (R. L. Gentry \& G. L. Kooyman, eds). Princeton University Press, Princeton, p. 168-185.

- (1986b). Maternal investment and sex allocation in the Galapagos fur seal, Arctocephalus galapagoensis. - Behav. Ecol. Sociobiol. 19, p. 157-164.

- - \& Dellinger, T. (ms). The effect of El Niño on Galapagos pinnipeds. - In: Pinnipeds and El Niño: Responses to environmental stress (F. Trillmich \& K. A. Ono, eds).

- \& Lechner, E. (1986). Milk of the Galapagos fur seal and sea lion, with a comparison of the milk of eared seals. - J. Zool. (Lond.) 209, p. 271-277.

- - \& Limberger, D. (1985). Drastic effects of El Niño on Galapagos pinnipeds. Oecologia 67, p. 19-22.

- -, Ono, K. A., Costa, D. P., Delong, R. L., Feldkamp, S., Francis, J. M., Gentry, R. L., Heath, C. B., Le Boeuf, B. J., Majluf, P. \& York, A. E. (ms). The ecological effects of El Niño on otariid and phocid populations. Summary and conclusion. - In: Pinnipeds and El Niño: Responses to environmental stress (F. Trillmich \& K. A. Ono, eds). 


\section{Zusammenfassung}

Ohrenrobben (Otariidae) sind eine Gruppe ähnlicher Arten, die von subpolaren bis in tropische Mecre verbreitet sind. In letzter Zeit wurden viele Arten während ozeanographischer Störungen unter Bedingungen niedrieger und hoher Nahrungsverfügbarkeit untersucht. Hinweise auf die phänotypische Flexibilität der Aufzuchtstrategie dieser Arten kann man aus inter- und intraspezifischen Vergleichen und experimentellen Messungen ableiten. Hier wird dargestellt, wie Änderungen der Nahrungsverfügbarkeit das Verhalten und den Energieaufwand bei der Jagd, die Wachstumsraten der Jungen, die Milchzusammensetzung, das Entwöhnungsalter und die Fertilitätskosten der Jungenaufzucht beeinflussen. Ohrenrobbenweibchen wechseln bei der Jungenaufzucht regelmäßig zwischen Laktation an Land und Nahrungssuche im Meer ab. Subpolare Seebärenarten entwöhnen Jungtiere immer im Alter von vier Monaten. Dieses Entwöhnungsalter scheint genetisch festgelegt zu sein und ist auf stark saisonale Umwelten angepaßt. Seebären und Seelöwen temperierter und tropischer Breiten können das Entwöhnungsalter flexibel an die Nahrungsverfügbarkeit anpassen. Abhängig von der Nahrungsverfügbarkeit regeln Mütter während der Jungenaufzucht ihre Körpermasse auf verschiedene Absolutwerte. Anscheinend ist die Körpermasse bei geringerer Jagdeffizienz, wie sie bei geringer Nahrungsdichte auftritt, zwangsläufig niedriger. Die meisten Arten jagen nachts, nur Seelöwen (Zalophus californianus) und Nördliche Seebären (Callorhinus ursinus) jagen auch tagsüber, müssen dann aber tiefer tauchen. Bei geringer Nahrungsverfügbarkeit steigern die Weibchen einiger Arten die Rate des Energieaufwandes auf See, halten aber die Jagdausflugslänge konstant, während die Weibchen anderer Arten länger im Meer bleiben und dafür mit gleicher Leistung arbeiten wei bei hoher Nahrungsverfügbarkeit. Die letzteren Arten scheinen Nahrungsspezialisten zu sein, die ein engeres zeitliches Fenster für Jagdaktivität haben. Jungtiere wachsen langsamer, wenn die Mütter länger im Meer bleiben. Bei sehr niedriger Nahrungsdichte können Jungtiere verhungern. Die Jungen können die Dauer der Abwesenheit ihrer Mütter wenig beeinflussen, können aber die Zeit ihres Aufenthaltes an Land verkürzen, indem sie schneller trinken oder lange saugen, obwohl keine Milch mehr kommt. Der Einfluß langer Abwesenheit der Mutter auf das Wachstum der Jungen wird dadurch verringert, daß der Fettgehalt der Milch zunimmt, wenn ein Weibchen länger auf See bleibt. Dieser Mechanismus kann aber die geringere Rate der Energie-aufnahme der Jungen bei längeren Jagdausflügen der Mutter nicht völlig kompensieren. Nicht-wandernde Arten können die Laktationsperiode verlängern und dadurch langsameres Wachstum der Jungen zum Teil ausgleichen. Eine Verlängerung der Laktationsperiode führt beim Galapagos Seebär (Arctocephalus galapagoensis) zu Fertilitätskosten. Laktation verringert die Wahrscheinlichkeit einer gleichzeitigen erfolgreichen Trächtigkeit und, wenn die Trächtigkeit doch zu Ende gebracht wird, gibt es Geschwisterkonkurrenz um die Milch der Mutter. Diese Konkurrenz führt meist zum Tode des Neugeborenen. Die Rate des Energietransfers an ein Jungtier ist in nahrungsreichen Jahren hoch und in nahrungsarmen niedrig. Bei hoher Wachstumsrate werden Jungtiere mit höherer Wahrscheinlichkeit im Alter von einem Jahr entwöhnt. Daher verringert hoher Ressourcentransfer im Jahr "a" die Kosten der Fortpflanzung, die im Jahr " $a+1$ " anfallen. Die Flexibilität der Fortpflanzungsstrategie von Arten temperierter und tropischer Meere ermöglicht Müttern, sich phänotypisch an Varianz im Nahrungsangebot anzupassen. 